\title{
Feeding behaviour of potential vectors of West Nile virus in Senegal
}

\author{
Assane G Fall ${ }^{1 *}$, Amadou Diaïté ${ }^{1}$, Renaud Lancelot ${ }^{2}$, Annelise Tran ${ }^{3,4}$, Valérie Soti ${ }^{3,4}$, Eric Etter ${ }^{4,6}$, Lassana Konaté ${ }^{5}$, \\ Ousmane Faye ${ }^{5}$ and Jérémy Bouyer ${ }^{1,2}$
}

\begin{abstract}
Background: West Nile virus (WNV) is a widespread pathogen maintained in an enzootic cycle between mosquitoes and birds with occasional spill-over into dead-end hosts such as horses and humans. Migratory birds are believed to play an important role in its dissemination from and to the Palaearctic area, as well as its local dispersion between wintering sites. The Djoudj Park, located in Senegal, is a major wintering site for birds migrating from Europe during the study period (Sept. 2008- Jan. 2009). In this work, we studied the seasonal feeding behaviour dynamics of the potential WNV mosquito vectors at the border of the Djoudj Park, using a reference trapping method ( $\mathrm{CDC}$ light $\mathrm{CO}_{2}$-baited traps) and two host-specific methods (horse- and pigeon-baited traps). Blood meals of engorged females were analysed to determine their origin.
\end{abstract}

Results: Results indicated that Culex tritaeniorhynchus and CX. neavei may play a key role in the WNV transmission dynamics, the latter being the best candidate bridging-vector species between mammals and birds. Moreover, the attractiveness of pigeon- and horse-baited traps for $C x$. neavei and $C x$. tritaeniorhynchus varied with time. Finally, $C X$. tritaeniorhynchus was only active when the night temperature was above $20^{\circ} \mathrm{C}$, whereas $C x$. neavei was active throughout the observation period.

Conclusions: $C X$. neavei and $C X$. tritaeniorhynchus are the main candidate vectors for the transmission of WNV in the area. The changes in host attractiveness might be related to variable densities of the migratory birds during the trapping period. We discuss the importance of these results on the risk of WNV transmission in horses and humans.

\section{Background}

West Nile fever (WNF) is an arthropod-borne disease caused by a Flavivirus (Flaviviridae) belonging to the Japanese encephalitis antigenic complex [1]. Birds are involved in its pathosystem. Horses and humans are dead-end hosts: their infection often remains unapparent but they can suffer febrile or even fatal illness with neural symptoms [2]. The West Nile virus (WNV) is highly endemic in Africa in general, and particularly in Senegal [3-5]. Migratory birds may be involved in spreading the virus in Africa, Europe, the Middle East and south-western Asia, especially through the Palaearctic migration routes where major flyways are crossing each other [6]. Such transcontinental introduction must

\footnotetext{
* Correspondence: agueyefall@yahoo.fr

${ }^{1}$ Institut Sénégalais de Recherches Agricoles/Laboratoire National de I'Elevage et de Recherches Vétérinaires BP 2057 Dakar-Hann, Sénégal Full list of author information is available at the end of the article
}

be anchored to local (African) spreading mechanism especially at birds' nesting, feeding, or resting sites where vector feeding behaviour probably plays a critical role [7].

The Senegal River delta (northern Senegal and southern Mauritania) is characterized by a mixture of natural wetlands and extensive irrigated agricultural activity. It is one of the major wintering sites for birds migrating between Europe and Africa that benefit from abundant food resources in the Djoudj National Park, where this study was conducted. The majority of the bird species migrating from Europe arrive there during the month of October and start their return flight during March/April [8].

A number of mosquito candidate vectors for the transmission of WNV have been identified in Senegal: Culex poicilipes, Cx. naevei, Mymomia spp., Mymomia hispida, M. lacustris, M. splendens, Aedomya africana [5], A. vexans and Mansonia uniformis [9]. All these
C Biomed Central 
species have a nocturnal feeding behaviour. However, little is known regarding their host preferences, especially regarding species feeding both on birds and mammals. The main objective of this study was to assess their feeding behaviour and its seasonality during the period of high risk of transmission of WNV in the area [3], to identify potential factors increasing the transmission between birds, and more importantly, from birds to mammals.

The study was conducted in Ross Bethio, a small town located $10 \mathrm{~km}$ south from the Djoudj National Park, Senegal (Figure 1). In 2005, a serological survey carried out on horses in this region highlighted high WN prevalence rates $(0.85 ; \mathrm{n}=367 ; 95 \%$ CI $0.81-0.89)$ [10].

The landscape surrounding Ross-Bethio is characterized by grasslands, shrublands and dry saline flats ("tans"). This area is also one of the main agricultural centres in the Senegal River delta, rice and sugar cane representing the main crops. During the dry season (from November to May), green vegetation is limited to some scattered trees and shrubs. During the rainy season (June to October: mean annual rainfall ca. $250 \mathrm{~mm}$ ), an herbaceous layer is available for domestic ruminants, donkeys and horses. The latter is used for ploughing, transporting goods and humans, and social distinction. The Senegal River valley, including the delta, is flooded each year either by rainfall water naturally collected in the upper Senegal River basin, or by planned water releases from the Manantali dam (upper Senegal River,
Mali) while retaining water with the Diama dam located near Ross Bethio. In Ross Bethio, the maximum flooding level is usually observed in early November.

\section{Results}

In total, 28,965 female mosquitoes, representing 12 species in 5 genera, were captured in all traps over 79 nights from September 2008 to January 2009. Mosquitoes from the Culex genus represented $95 \%(27,443)$ of the total captures. The predominant species were $C x$. tritaeniorhynchus, $C x$. neavei and $C x$. poicilipes, representing $69.4 \%(20,109), 19.7 \%(5,702)$ and $5.4 \%(1,575)$ of the total captures respectively. $\mathrm{CDC}$ light $\mathrm{CO}_{2}$-baited traps were the most efficient with 20,382 female mosquitoes (apparent nightly density per trap - ANT of the total collection $=566.2$ ) in 11 species belonging to 5 genera closely followed by the horse-baited trap with 7402 female mosquitoes (ANT of the total collection $=$ 493.5) in 8 species and 4 genera. Pigeon-baited traps collected 1,181 (ANT of the total collection = 42.2) mosquitoes in 6 species and 2 genera (Table 1).

The predominance of $C x$. tritaeniorhynchus and $C x$. neavei over the other species was also clearly showed on the table 1 . The ANTs within a given trap type were correlated between sites $(p<0.05)$. Whereas $C x$. tritaeniorhynchus was mainly mammophilic, $C x$. neavei was attracted by both horses and birds.

A strong seasonality was observed in the attractiveness of each host for $C x$. neavei and $C x$. tritaeniorhynchus. The

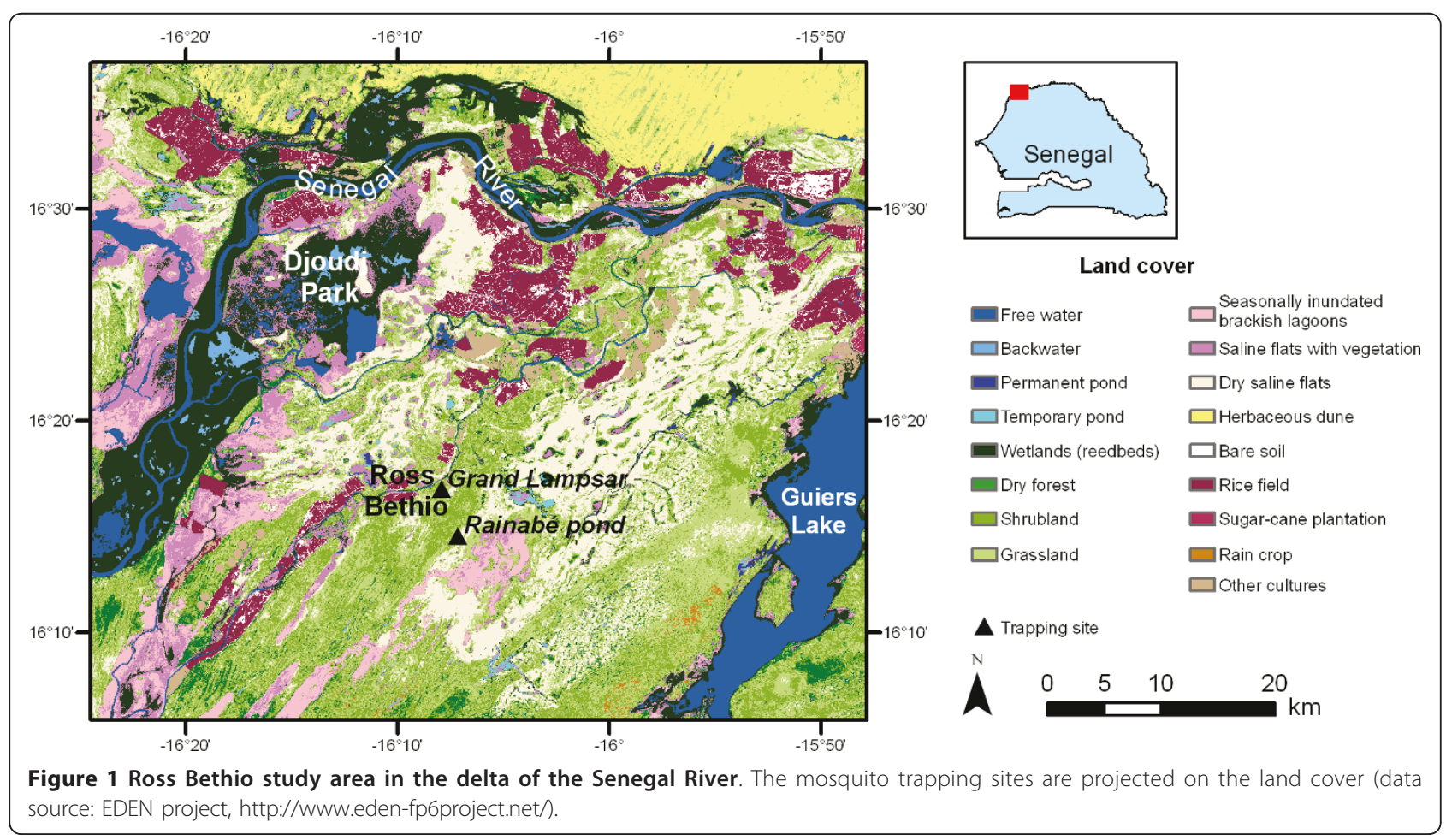


Table 1 Mean apparent mosquito densities in the Senegal River delta

\begin{tabular}{|c|c|c|c|c|c|c|}
\hline \multirow[b]{2}{*}{ Mosquito species } & \multicolumn{3}{|c|}{ CDC light CO2-baited traps } & \multirow{2}{*}{$\begin{array}{c}\text { Horse-baited trap } \\
\text { RB }(n=15)\end{array}$} & \multicolumn{2}{|c|}{ Pigeon-baited traps } \\
\hline & $\begin{array}{l}\text { GL ground } \\
(\mathrm{n}=15)\end{array}$ & $\begin{array}{l}\text { GL canopy } \\
(\mathrm{n}=12)\end{array}$ & $\begin{array}{l}\text { RM ground } \\
(\mathrm{n}=9)\end{array}$ & & $\begin{array}{l}\text { GL ground } \\
(n=14)\end{array}$ & $\begin{array}{l}\text { GL canopy } \\
(\mathrm{n}=14)\end{array}$ \\
\hline Culex neavei & $53.7 \pm 53.41$ & $106.3 \pm 121.51$ & $10.4 \pm 21.54$ & $176.7 \pm 275.47$ & $3.3 \pm 4.16$ & $59.4 \pm 38.82$ \\
\hline Culex tritaeniorynchus & $540.3 \pm 755.92$ & $408.1 \pm 674.02$ & $331.5 \pm 540.06$ & $257.4 \pm 485.02$ & $1.6 \pm 3.71$ & $17.4 \pm 33.36$ \\
\hline Aedes sudanensis & 0 & $0.1 \pm 0.29$ & $0.7 \pm 1.12$ & 0 & 0 & 0 \\
\hline Mansonia uniformis & $21.2 \pm 21.92$ & $18.3 \pm 24.50$ & $5 \pm 5.96$ & $2.2 \pm 3.23$ & $0.4 \pm 0.74$ & $0.5 \pm 0.85$ \\
\hline Aedomyia africana & $0.1 \pm 0.35$ & $2.1 \pm 2.75$ & 0 & $0.1 \pm 0.26$ & 0 & 0 \\
\hline Anopheles rufipes & 0 & $0.1 \pm 0.29$ & $0.1 \pm 0.33$ & $0.1 \pm 0.26$ & 0 & 0 \\
\hline Anopheles pharoensis & $6.3 \pm 7.82$ & $3.2 \pm 3.54$ & $4.8 \pm 8.67$ & $29.8 \pm 44.25$ & 0 & 0 \\
\hline Anopheles ziemanni & $4.3 \pm 7.50$ & $3.9 \pm 6.72$ & $1.8 \pm 2.49$ & $7.1 \pm 8.67$ & 0 & 0 \\
\hline Culex bitaeniorhynchus & $0.9 \pm 1.39$ & $0.2 \pm 0.39$ & $2 \pm 4.69$ & 0 & 0 & $0.2 \pm 0.43$ \\
\hline Culex theileri & 0 & 0 & 0 & 0 & 0 & $0.1 \pm 0.27$ \\
\hline Culex poicilipes & $16.3 \pm 15.96$ & $68 \pm 89.94$ & $21.2 \pm 49.73$ & $20.1 \pm 26.33$ & 0 & $1.6 \pm 2.82$ \\
\hline Culex perfuscus & $0.7 \pm 1.39$ & $0.3 \pm 0.89$ & $0.1 \pm 0.33$ & 0 & 0 & 0 \\
\hline
\end{tabular}

Mean values per trap per night \pm standard deviation for each mosquito species during the whole trapping period are presented according to the trap type, height and location ( $\mathrm{RB}=$ Ross Bethio, $\mathrm{GL}=$ Grand Lampsar, $\mathrm{RM}=$ Raïnabé tempory pound, $\mathrm{n}=$ number of trap-nights).

ANTs of Cx. neavei and Cx. tritaeniorhynchus were highest in September and October in the horse-baited trap and then decreased until January. In pigeon-baited traps, they increased in October for both species and remained stable for $C x$. neavei whereas they decreased again until January for Cx. tritaeniorhynchus (Figure 2). In October, both mosquito species fed on horses and birds.

The height of the trap had an impact on host attractiveness. In the $\mathrm{CDC}$ light $\mathrm{CO}_{2}$-baited traps, the ANTs of the two predominant species $(C x$. tritaeniorhynchus and $C x$. neavei) did not differ significantly when placed at the ground or in the tree canopy in Grand Lampsar $(p>0.05)$. On the other hand, these ANTs differed significantly between heights in pigeon-baited traps for $C x$. tritaeniorhynchus $(p=0.02)$, and $C x$. neavei $(p=$ $\left.4 \times 10^{-5}\right)$. These differences were significant only after October (Figure 3). Whereas the ANTs in the $\mathrm{CO}_{2}$-baited CDC traps decreased during the study both in the tree canopy and on the ground (as with the horse-baited traps), they increased sharply in October for both species in the pigeon-baited traps, particularly in the tree canopy, and remained stable for $C x$. neavei until the end of the study period, whereas they decreased again in Cx. tritaeniorhynchus.

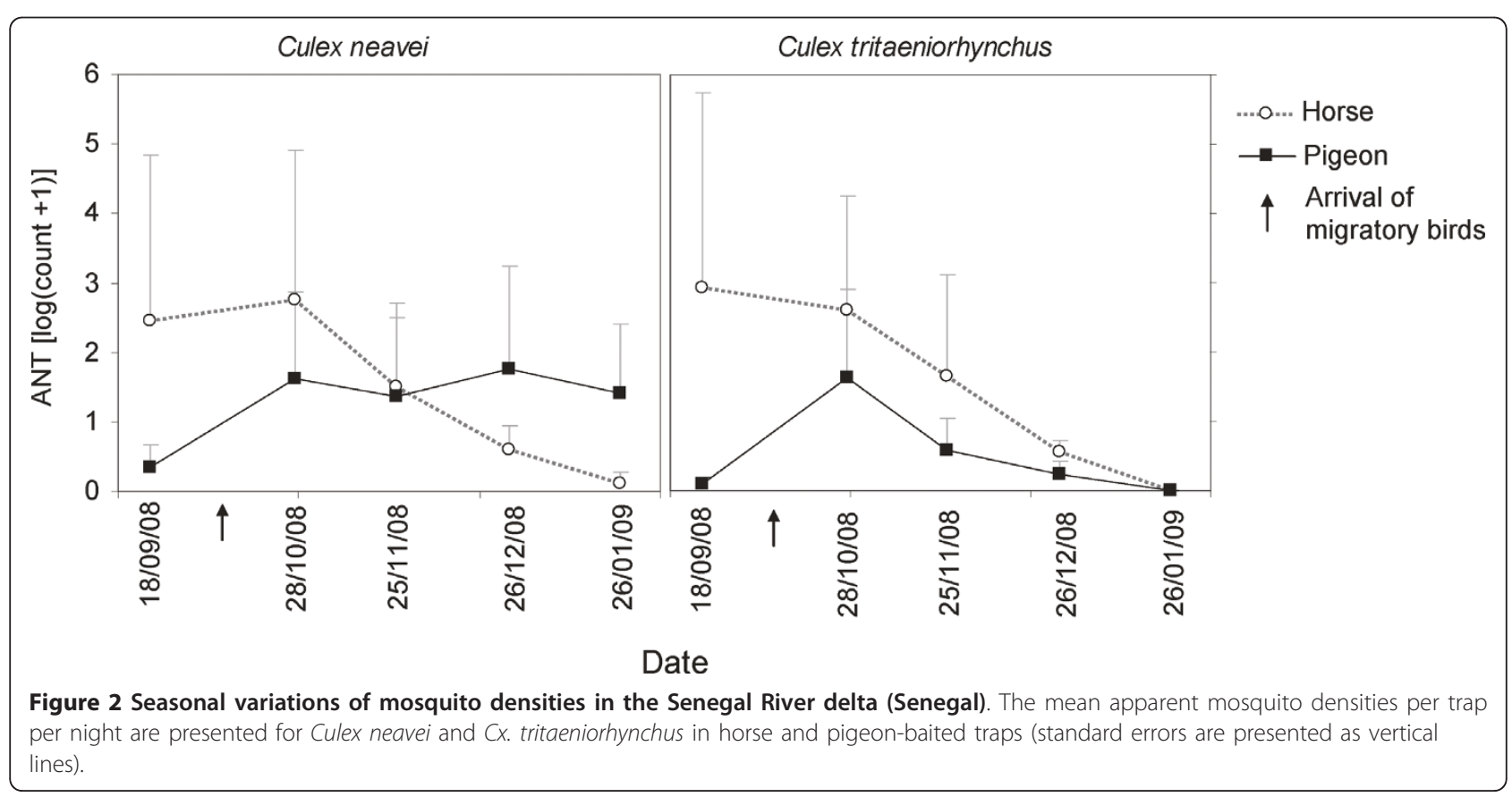



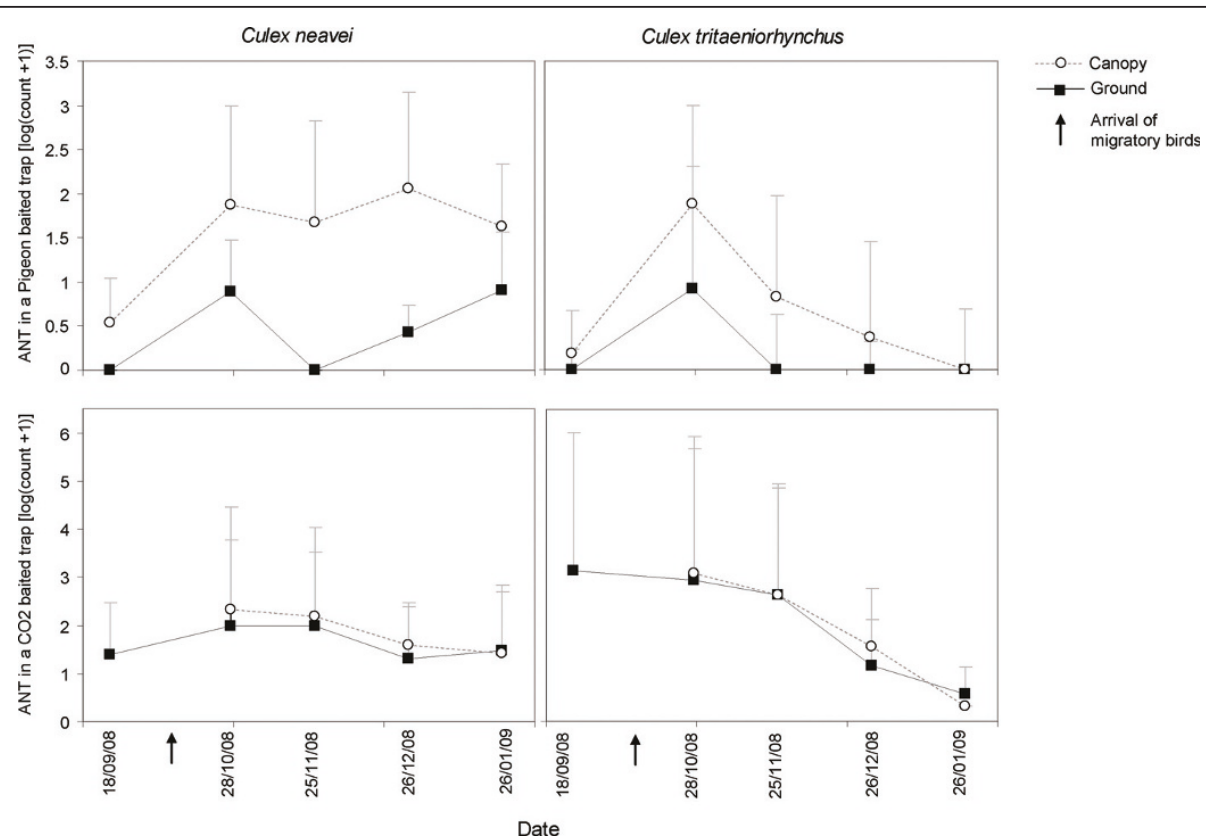

Figure 3 Seasonal variations of mosquito densities according to trap location at Grand Lampsar River, in the Senegal River delta. The mean apparent mosquito densities per trap per night are presented for Culex tritaeniorhynchus and $C x$. neavei according to the location of the pigeon- and $\mathrm{CO}_{2}$ - baited traps, on the ground or in the tree canopy (standard errors are presented as vertical lines).

Most of the engorged mosquitoes were collected from the $\mathrm{CO}_{2}$-baited traps placed on the ground (38 out of 45). Blood meals analyses (Table 2) revealed that $C x$. neavei fed mainly on birds, followed by humans, cattle and horses. Culex tritaeniorhynchus blood meals were taken on horses, humans, cattle, and birds. Mixed meals identified from Cx. tritaeniorhynchus (14\% of total blood meals) were associations between sheep and cattle (50\%), human and cattle (25\%) and human and horse (25\%).

There was no relationship either between the temperature or the relative hygrometry and the ANTs of $C x$. neavei $(p=0.82)$. Conversely, the ANTs of $C x$. tritaeniorhynchus were correlated with temperature $(p=$ $0.001)$ and relative hygrometry $\left(p=7 \times 10^{-9}\right)$. Indeed, the activity of $C x$. tritaeniorhynchus was very low when temperature was below $20^{\circ} \mathrm{C}$ and $\backslash$ or the relative hygrometry was below $55 \%$ (Figure 4 ).

\section{Discussion}

Greater mosquito numbers and higher species diversity were caught in $\mathrm{CO}_{2}$-baited $\mathrm{CDC}$ light traps, as compared with the other traps. $\mathrm{CO}_{2}$-baited $\mathrm{CDC}$ light traps allow a representative census of the mosquito diversity in a given area, particularly arbovirus vectors in Senegal $[5,11,12]$. All captured mosquito species, but $C x$. theileri, were recorded in these traps in Ross Béthio. Indeed, the latter seems to be very rare in the area. Only 45 females $(0.2 \%)$ were found engorged. Such a low proportion has been observed in other studies [13]: indeed, starving mosquitoes are more attracted by $\mathrm{CO}_{2}$-baited traps (which mimic hosts' breath) than engorged mosquitoes.

Culex poicilipes, $C x$. tritaeniorhynchus, $C x$. neavei, and Mansonia uniformis were the most abundant mosquito species given the traps used. In Senegal, WNV has been isolated, or WN viral ribonucleic acid has been detected, from each of these species $[5,12,14]$. The competence of

Table 2 Origin of mosquito bloodmeals in the Senegal River delta

\begin{tabular}{|c|c|c|c|c|c|c|c|c|c|}
\hline \multirow[b]{2}{*}{$\begin{array}{l}\text { Mosquito } \\
\text { species }\end{array}$} & \multirow[b]{2}{*}{$\begin{array}{l}\text { Total number of } \\
\text { samples }\end{array}$} & \multicolumn{7}{|c|}{ Vertebrate hosts (\%) } & \multirow[b]{2}{*}{$\begin{array}{l}\text { Not identified blood } \\
\text { meals (\%) }\end{array}$} \\
\hline & & Horse & Cattle & Birds & Human & $\begin{array}{l}\text { Cattle, } \\
\text { Sheep }\end{array}$ & $\begin{array}{l}\text { Human, } \\
\text { Cattle }\end{array}$ & $\begin{array}{l}\text { Human, } \\
\text { Horse }\end{array}$ & \\
\hline CX. neavei & 14 & $1(7.1)$ & $\begin{array}{c}2 \\
(14.3)\end{array}$ & $\begin{array}{c}4 \\
(28.6)\end{array}$ & $3(21.4)$ & $0(0.0)$ & $0(0.0)$ & $0(0.0)$ & $4(28.6)$ \\
\hline $\begin{array}{l}\text { Cx. } \\
\text { tritaeniorhynchus }\end{array}$ & 28 & $\begin{array}{c}10 \\
(35.7)\end{array}$ & $\begin{array}{c}4 \\
(14.3)\end{array}$ & 1(3.6) & $5(17.8)$ & $2(7.1)$ & $1(3.6)$ & 1(3.6) & $4(14.3)$ \\
\hline
\end{tabular}

The results are presented for Culex neavei and Cx. tritaeniorhynchus captured in CO2-baited CDC traps (percentage in brackets). 

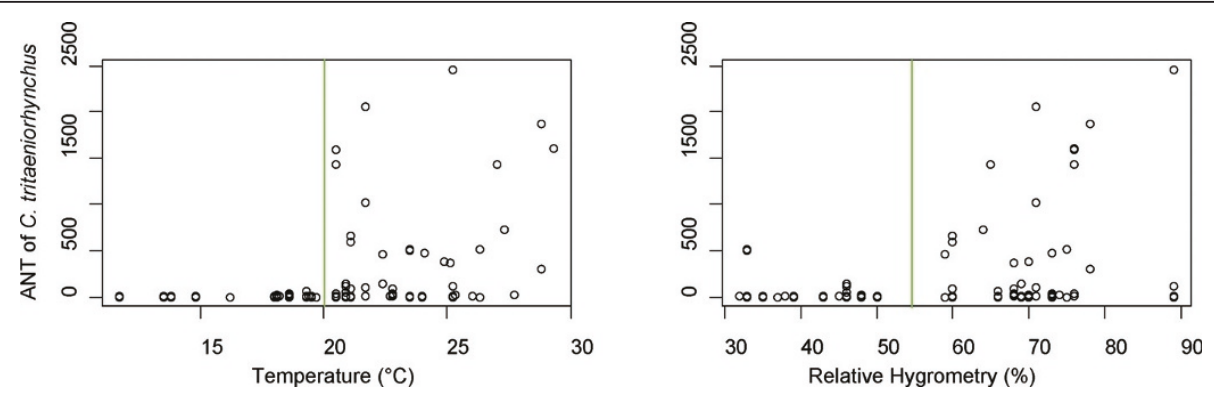

Figure 4 Impact of temperature and relative hygrometry on the density of mosquitoes in the Senegal River delta. The panels present the relationship between the mean apparent mosquito densities per trap per night of Culex neavei and $C$. tritaeniorhynchus and these meteorological parameters.

Cx. tritaeniorhynchus and Cx. neavei for the WNV has been demonstrated $[15,16]$. These two species are thus possible WNV vectors in this area. Regarding other mosquito species, virus isolations do not imply that these species are competent WNV vectors. It is only an indication that they had fed on viremic hosts.

Chevalier et al. [7] found higher prevalence rate $(p=3$ $\times 10^{-4}$ ) for WNV in resident birds resting on the ground $(0.10, n=88)$ than in those resting in the bush $(0.04, n$ $=125)$ or in the canopy $(0.04, n=209)$. In this study, pigeon baited-traps captured a lower diversity of mosquito species (5 Culex species and 1 Mansonia). The height of the pigeon baited-trap had an effect on its attractiveness for $C x$. tritaeniorhynchus and $C x$. neavei, conversely to the $\mathrm{CO}_{2}$-baited trap. However, this difference depended on the bait and the season, and was only noticeable from October, when the migratory birds are known to arrive from Palaearctic areas for wintering [17]. We also observed a shift of feeding hosts of $C x$. neavei and $C x$. tritaeniorhynchus starting in October, from horses to birds. However, the dataset is limited and the observed shift difficult to explain. Our main hypothesis is that they were caused by changes in host availability combined with host and site fidelity in these two mosquito species: the night resting sites of passerine birds is the tree canopy, and their increase in abundance might increase the attractiveness of pigeon-baited traps set in the tree canopy. Actually, host fidelity has been reported in other vector species $[18,19]$ while site fidelity has been reported in anophelines [20]. Host fidelity was also reported in experimental conditions for $C x$. tritaeniorhynchus [21]. Mark-release-recapture experiments also suggested that two other Culex species might "memorize" flight paths within their environment [22]. In tsetse flies, the decomposition of habitats into a "home range" and a "feeding ground" - between which insects would fly on purpose [23], was recently assessed using population genetics [24]. On the contrary, in opportunistic mosquitoes such as Aedes vexans arabiensis, the feeding behaviour is linked to host availability
[25]. Unfortunately, we could not validate these shifts in feeding patterns using the ELISA results because of limited sample size (only 45 blood-fed mosquitoes). This study should thus be repeated, including a follow up of the resting sites and abundance of birds from different orders (Passeriformes, Galliformes, Charadriiformes, etc.), and continued during the departure of migratory birds in March to April to confirm that the mosquitoes would go back to the available mammal hosts. In the Ferlo region of Senegal, $175 \mathrm{~km}$ south-east from Ross Bethio, $C x$. neavei was also found more abundant in the tree canopy than on the ground, using both pigeon- and chicken-baited traps [9].

The study period ranged from Sept. 2008 to Jan. 2009, corresponding to the wintering of European bird species in the Djoudj National Park [8,17], as well as to a high density of potential mosquito WN vectors: end of rainy season, flooding of the Senegal River Valley, optimum temperature and relative hygrometry for the development and the survival of vectors. A prospective serological survey carried out during the same time period on a cohort of seronegative horses, showed that WNV circulation occurred mainly between October and January in Ross Bethio (Diouf, pers. com.). The same WNV transmission period was observed in sentinel chicken in the Ferlo [3], also when surface water and mosquitoes were abundant, and the migratory birds arrived in the area [26].

If the shift of feeding patterns were to be confirmed, it might favour the transmission of the WNV from birds to horses. Actually, between-bird WNV transmission [27] would be increased due to a higher ornithophilic tropism in $C x$. neavei when birds occur at high densities, but then the risk of WNV transmission to horses and humans would increase again with the departure of birds. Results of blood meal analyses confirmed that humans were the second hosts after horses in $C x$. tritaeniorhynchus, and after birds in $C x$. neavei. Such shifts from birds to humans were demonstrated for Culex pipiens and Cx. tarsalis in North America [28]. They 
were governed by the dispersal of their bird preferred hosts and lead to higher risk of WNV infection in human.

Lastly, the activity of Cx. tritaeniorhynchus was governed by a threshold in temperature/hygrometry (Figure 4), which was not observed for $C x$. neavei.

\section{Conclusions}

Without neglecting the possible role of other mosquito species in the transmission of the WNV, results obtained in this study suggest that i) $C x$. neavei and $C x$. tritaeniorhynchus are the main candidate vectors for the transmission of WNV, ii) $C x$. neavei is probably a permanent between-bird vector, and a seasonal bridge vector between birds and mammalian hosts, iii) $C x$. tritaeniorynchus is probably a seasonal less important bridge vector between birds and mammalian hosts.

\section{Methods}

\section{Trapping systems}

The Centers for Disease Control and Prevention (CDC) light trap [29] baited with $\mathrm{CO}_{2}$ was used as the reference trap. It was compared with animal-baited traps using pigeons and horses. The horse-baited trap was a steel cage $(2.5 \times 1.5 \times 2 \mathrm{~m})$ containing a horse and covered with a mosquito netting $(4 \times 3.5 \times 2.5 \mathrm{~m})$ hanging approximately at $15 \mathrm{~cm}$ from the ground, thus allowing the mosquitoes to enter. This model was used by Balenghien et $a l$. [30] to study the potential WNV vectors during an outbreak of this disease in Southern France. The pigeon-baited trap was a plastic cylinder of $31.5 \mathrm{~cm}$ diameter and $90 \mathrm{~cm}$ length divided into 3 compartments. The central compartment was $50 \mathrm{~cm}$ long and contained the pigeon box. The two lateral compartments measured each $20 \mathrm{~cm}$ and were closed at their sides akin to the central compartment by a mosquito net. Funnel of mosquito netting with an internal opening of about $3 \mathrm{~cm}$ of diameter were fixed to the outside sides and allowed the mosquitoes to enter. Darbro and Harrington [31] used this trap model for surveillance of $\mathrm{WN}$ mosquito vectors in the New York state (USA). Mosquitoes captured in these animal-baited traps were collected by aspiration.

\section{Study site}

The CDC light $\mathrm{CO}_{2}$-baited trap was set near the Grand Lampsar River $\left(16.279^{\circ} \mathrm{N}, 16.132^{\circ} \mathrm{W}\right)$, a tributary of the Senegal River and near the Rainabe temporary pond $\left(16.242^{\circ} \mathrm{N}, 16.119^{\circ} \mathrm{W}\right)$ (Figure 1). The pigeon baited traps were set only near the Grand Lampsar River. CDC light $\mathrm{CO}_{2}$-baited trap and pigeon baited traps were placed either at about $1.5 \mathrm{~m}$ high from the ground, or at about $6 \mathrm{~m}$ high in the tree canopy, at the extremities of square of about 10 by $10 \mathrm{~m}$. The horse-baited trap was placed in the stable of a horse owner in Ross Bethio $\left(16.268^{\circ} \mathrm{N}, 16.133^{\circ} \mathrm{W}\right)$.
Mosquito traps were set overnight from $6 \mathrm{pm}$ to 6 am during three consecutive days, monthly from 16 Sept. 2008 to 28 Jan. 2009. Mosquitoes were identified using the morphological keys of Edwards [32] for the Culicinae subfamily and Diagne et al. [33] for the Anophelinae subfamily. Engorged females collected in CDC light $\mathrm{CO}_{2}$-baited traps were placed in tubes individually and stored at $-20^{\circ} \mathrm{C}$ until the determination of the origin of their blood meal. The ELISA technique developed by Beier et al. [34] was used for these analyses. The choice of conjugates was done taking into account the potential hosts frequenting the trapping sites. The following conjugates were thus used: anti-human, anti-sheep, anti-cattle, anti-chicken, and anti-horse.

Temperature and relative hygrometry data were also collected with the Thermo-Hygro sensor (model NO. THGR228N HUGER ${ }^{\circledR}$ ) placed in each trapping site. During the 2008 rainy season, the last rains were recorded in the second half of September: no rain was thus recorded during our study.

\section{Statistical analyses}

Trap attractiveness for each mosquito species was computed as the mean number of mosquito individuals from this species in a given trap during three consecutive night catches, also called the mean apparent nightly density per trap (ANT).

A principal component analysis [35] was applied to the whole dataset, with the mosquito species as the individuals and the mean ANTs of each species over the whole period by trap type, height (canopy versus ground) and site as variables, to explore the capture pattern of the various species and the correlations between the trapping systems.

The mean ANTs between sites or heights were compared altogether using a Kruskal-Wallis rank sum test [36], then using a Wilcoxon rank sum test [36].

The $\mathrm{R}$ software package was used for statistical analyses [37].

\section{Acknowledgements}

We thank Dr Yaya Thiongane, Dr Magatte Ndiaye, Dr Omar Talla Diaw, Dr Momar Talla Seck and Mr Iba Mall (ISRA-LNERV), Dr Ibrahima Dia (IPD), as well as Mr Abdou Fall, veterinary officer of Ross-Bethio. We are also thankful to Nicolas Gaidet for providing important data on the migration period of birds in our study area. This work was partially supported by the EU grant GOCE-2003-010284 EDEN; this paper is catalogued by the EDEN Steering Committee as EDEN0250 (http://www.eden-fp6project.net/). No additional external funding was received for this study. The contents are the sole responsibility of the authors and do not necessarily reflect the views of the European Commission. The funders had no role in study design, data collection and analysis, decision to publish, or preparation of the manuscript.

\section{Author details}

${ }^{1}$ Institut Sénégalais de Recherches Agricoles/Laboratoire National de l'Elevage et de Recherches Vétérinaires BP 2057 Dakar-Hann, Sénégal.

${ }^{2}$ Centre International en Recherche Agronomique pour le Développement 
(CIRAD), UMR CIRAD-INRA Contrôle des maladies animales exotiques et émergentes, Campus international de Baillarguet, 34398 Montpellier Cedex 5, France. ${ }^{3}$ CIRAD, UMR TETIS, Maison de la Télédétection, 34093 Montpellie Cedex 5, France. ${ }^{4} \mathrm{CIRAD}$, UR Animal et Gestion Intégrée des Risques (AGIRs), 34398 Montpellier Cedex 5, France. ${ }^{5}$ Département de Biologie Animale, Faculté des Sciences et Techniques, Université Cheikh Anta Diop, Dakar Sénégal. ${ }^{6}$ Department Environment and Societies, TREP Building, University of Zimbabwe, P.O. Box 1378, Harare, Zimbabwe.

\section{Authors' contributions}

AGF and $A D$ designed and performed the experiment, and wrote the first draft of the manuscript. AT and VS designed the study area figure and documented it in the draft. AGF, RL and JB designed figures and performed statistical analyses. RL, JB, EE, OF and LK contributed to the manuscript redaction and revised it critically. All authors read and approved the final version of the manuscript.

\section{Competing interests}

The authors declare that they have no competing interests.

Received: 5 April 2011 Accepted: 8 June 2011 Published: 8 June 2011

\section{References}

1. Calisher CH, Karabatsos N, Dalrymple JM, Shope RE, Porterfield JS, Westaway EG, Brandt WE: Antigenic relationships between flaviviruses as determined by cross-neutralization tests with polyclonal antisera. J Gen Virol 1989, 70:37-43.

2. Hubalek Z, Halouzka J: West Nile virus - a reemerging mosquito-borne viral disease in Europe. Emerg Infect Dis 1999, 5:643-650.

3. Chevalier V, Lancelot R, Diaïte A, Mondet B, Lamballerie X: Use of sentinel chickens to study the transmission dynamics of West Nile virus in a Sahelian ecosystem. Epidemiol Inf 2008, 136:525-528.

4. Cabre O, Grandadam M, Marié JL, Gravier P, Prangé A, Santinelli Y, Rous V, Bourry O, Durand JP, Tolou H, Davoust B: West Nile Virus in horses, subSaharan Africa. Emerg Infect Dis 2006, 12:1958-1960.

5. Traore-Lamizana M, Zeller HG, Mondo M, Hervy JP, Adam F, Digoutte JP. Isolation of West Nile and Bagaza viruses from mosquito (Diptera Culicidae) in central Senegal (Ferlo). J Med Entomol 1994, 31:934-938

6. Rappole J, Derrickson S, Hubálek Z: Migratory birds and spread of West Nile virus in the western hemisphere. Emerg Infect Dis 2000, 6:319-328.

7. Chevalier V, Reynaud P, Lefrançois T, Durand B, Baillon F, Balança G, Gaidet N, Mondet B, Lancelot R: Predicting West Nile Virus Seroprevalence in Wild Birds in Senegal. Vector-Borne Zoon Dis 2009 9:589-596.

8. Morel G: Contribution à la synécologie des oiseaux du Sahel sénégalais Paris, ORSTOM; 1968.

9. Diallo D, Ba Y, Dia I, Sall AA, Diallo M: Evaluation of the efficiency of birdbaited traps for sampling potential West Nile fever mosquito vectors (Diptera: Culicidae) in Senegal. Parasite 2010, 17:143-147.

10. Chevalier V, Dupressoir A, Tran A, Diop OM, Gottland C, Diallo M, Etter E, Ndiaye M, Grosbois V, Dia M, et al: Environmental risk factors of West Nile virus infection of horses in the Senegal River basin. Epidemiol Inf 2010, 23:1-9.

11. Traore-Lamizana M, Fontenille D, Diallo M, Ba Y, Zeller HG, Mondo M, Adam F, Thonnon J, Maiga A: Arbovirus surveillance from 1990 to 1995 in the Barkedji area (Ferlo) of Senegal, a possible natural focus of Rift Valley fever virus. J Med Entomol 2001, 38:480-492.

12. Diallo $M$, Nabeth $P, B a$ K, Sall AA, Ba Y, Mondo M, Girault L, Abdalahi MO, Mathiot C: Mosquito vectors of the 1998-1999 outbreak of Rift Valley Fever and other arboviruses (Bagaza, Sanar, Wesselsbron and West Nile) in Mauritania and Senegal. Med Vet Entomol 2005, 19:119-126.

13. Williams GM, Gingrich JB: Comparison of light traps, gravid traps, and resting boxes for West Nile virus surveillance. J Vect Ecol 2007, 32:285-291.

14. CRORA database (Base de données sur les virus africains 2005): virus West Nile. [http://www.pasteur.fr/recherche/banques/CRORA/virus/v010100. $\mathrm{htm}]$.

15. Turell MJ, Mores CN, Dohm DJ, Lee W-J, Kim H-C, Klein TA: Laboratory transmission of Japanese Encephalitis, West Nile, and Getah viruses by mosquitoes (Diptera: Culicidae) collected near Camp Greaves, Gyeongg Province, Republic of Korea, 2003. J Med Entomol 2006, 43:1076-1081.
16. Jupp PG, Mclntosh BM, Blackburn NK: Experimental assessment of the vector competence of Culex (Culex) neavei Theobald with West Nile and Sindbis viruses in South Africa. Trans R Soc Trop Med Hyg 1986, 80:226-230.

17. Morel GJ, Roux F: Les migrateurs paléarctiques au Sénégal. II. Passereaux et synthèse générale. Rev Ecol (Terre Vie) 1966, 2:143-176.

18. McCall PJ, Kelly DW: Learning and memory in disease vectors. Trends Parasitol 2002, 18:429-433.

19. Bouyer J, Pruvot $M$, Bengaly $Z_{\text {, Guerin } P M}$, Lancelot R: Learning influences host choice in tsetse. Biol Lett 2007, 3:113-116.

20. McCall PJ, Mosha FW, Njunwa KJ, Sherlock K: Evidence for memorized sitefidelity in Anopheles arabiensis. Trans R Soc Trop Med Hyg 2001, 95:587-590.

21. Mwandawiro C, Bootsa M, Tunoa N, Suwonkerdb W, Tsudaa Y, Takag M: Heterogeneity in the host preference of Japanese encephalitis vectors in Chiang Mai, Northern Thailand. Trans R Soc Trop Med Hyg 2000, 94:238-242.

22. Reisen WK, Lothrop HD, Lothrop B: Factors Influencing the Outcome of Mark-Release-Recapture Studies with Culex tarsalis (Diptera: Culicidae). J Med Entomol 2003, 40:820-829.

23. Jackson CHN: The Economy of a Tsetse Population. Bull Ent Res 1941, 32:53-55.

24. Bouyer J, Balenghien T, Ravel S, Vial L, Sidibé I, Thévenon S, Solano P, De Meeûs T: Population sizes and dispersal pattern of tsetse flies: rolling on the river? Mol Ecol 2009, 18:2787-2797.

25. Fall AG, Diaité A, Etter E, Bouyer J, Ndiaye TD, Konaté L: Aedes vexans arabiensis (Diptera, Culicidae) as a probable vector bridging West Nile virus between birds and horses in Barkedji (Ferlo, Senegal). Med Vet Entomol 2011.

26. Morel GJ, Morel M-Y: Recherches écologiques sur une savane sahélienne du Ferlo septentrional, Sénégal. Etude d'une communauté avienne. Cah ORSTOM, sér Biol 1978, 13:3-34.

27. Hartemink NA, Davis SA, Reiter P, Hubálek Z, Heesterbeek JA: Importance of bird-to-bird transmission for the establishment of West Nile virus. Vector-Borne Zoon Dis 2007, 7:575-584.

28. Kilpatrick AM, Kramer LD, Jones MJ, Marra PP, Daszak P: West Nile Virus Epidemics in North America Are Driven by Shifts in Mosquito Feeding Behavior. Plos Biol 2006, 4:e82.

29. Sudia WD, Chamberlain RW: Battery-operated light trap, an improved model. Mosa News 1962, 22:126-129.

30. Balenghien T, Fouque F, Sabatier P, Bicout DJ: Horse-, bird-, and humanseeking behavior and seasonal abundance of mosquitoes in a West Nile virus focus of southern France. J Med Entomol 2006, 43:936-946.

31. Darbro JM, Harrington LC: Bird-baited traps for surveillance of West Nile mosquito vectors: effect of bird species, trap height, and mosquito escape rates. J Med Entomol 2006, 43:83-92.

32. Edwards FW: Mosquitoes of the Ethiopian region. III Culicine Adults and Pupae London, British Museum (Natural History); 1941.

33. Diagne N, Fontenille D, Konaté L, Faye O, Traore-Lamizana M, Legros F, Molez JF, Trape JF: Les anophèles du Sénégal. Liste commentée et illustrée. Bull Soc Pathol Exot 1994, 87:267-277.

34. Beier JC, Perkins PV, Wirtz RA, Koros J, Diggs D, Gargan TP, Koech DK: Bloodmeal identification by direct enzyme-linked immunosorbent assay (ELISA) tested on Anopheles (Diptera: Culicidae) in Kenya. J Med Entomol 1988, 25:9-1.

35. Manly BFJ: Multivariate statistical methods: a primer London, Chapman \& Hall/CRC; 2005

36. Hollander M, Wolfe DA: Non parametric statistical inference New York, John Wiley \& Sons; 1973.

37. R: A language and environment for statistical computing. [http://www.Rproject.org].

doi:10.1186/1756-3305-4-99

Cite this article as: Fall et al:: Feeding behaviour of potential vectors of West Nile virus in Senegal. Parasites \& Vectors 2011 4:99. 